Check for updates

New York

Cite this as: BMJ 2020;370:m3396 http://dx.doi.org/10.1136/bmj.m3396 Published: 02 September 2020

\section{Covid-19: US will not join WHO in developing vaccine}

\author{
Janice Hopkins Tanne
}

The Trump administration said on 1 September that it would not join Covax, the initiative led by the World Health Organization to develop and distribute a covid-19 vaccine.

A White House spokesman told the Washington Post, "The United States will continue to engage our international partners to ensure we defeat this virus, but we will not be constrained by multilateral organizations influenced by the corrupt World Health Organization and China.”

President Donald Trump withdrew the US from WHO in July because he considered that it favored China, despite protests by health experts. ${ }^{2}$ Each year the US gives WHO about $\$ 450 \mathrm{~m}$ (£337m; $\left.€ 379 \mathrm{~m}\right)$, which provides about $15 \%$ of WHO's budget.

The WHO Covax plan is co-led by the Coalition for Epidemic Preparedness Innovations; Gavi, the Vaccine Alliance; and WHO. ${ }^{3}$ It involves 172 countries that will work in a global initiative to develop and produce covid-19 vaccines. WHO has said that it has the world's largest and most diverse vaccine portfolio: nine candidate vaccines and another nine under evaluation.

\section{Yielding to pressure}

Stephen Hahn, head of the US Food and Drug Administration, told the Financial Times on 30 August that he might approve the emergency use of a US vaccine against covid-19 before phase III trials were completed. The next day he insisted, "Science and data drive our decisions." 45

Hahn has been criticized for yielding to pressure from Trump to approve treatments for covid-19 too quickly, before the 3 November election. Peter Marks, head of the FDA's Center for Biologics Evaluation and Research, said earlier that he would quit if the Trump administration pressed for too quick an approval of a vaccine. ${ }^{6}$

Early release of vaccines in the past has shown that problems can arise. In 1955 the injectable polio vaccine was approved, but a batch produced by Cutter Laboratories contained live virus. Several hundred children were paralyzed, and a few died. ${ }^{7}$ In 1976 President Gerald Ford-like Trump, facing an election-promoted a vaccination campaign against swine flu despite controversy over the vaccine's safety. About 500 cases of Guillain-Barre syndrome occurred in people who had received that vaccine. ${ }^{8}$

\section{Phases for allocation}

Trump has repeatedly said that a covid vaccine will be available very soon, perhaps before the US election. Public health experts such as Anthony Fauci, head of the National Institute of Allergy and Infectious Diseases, have said that a vaccine may be possible by the end of the year but that some time in the first six months of 2021 is more likely.

Hahn had given early approval to the use of hydroxychloroquine as a treatment for covid-19. Trump praised the drug and said that he had taken it himself for two weeks. The FDA later retracted the approval, cautioning about the risk of serious cardiac adverse effects. ${ }^{9}$ Hahn has also been criticized for overstating the effectiveness of convalescent plasma as a treatment at a press conference. That statement was corrected on 1 September to show more modest benefit. ${ }^{10}$

On the same day, the National Academies of Science released a preliminary report on guidelines for allocating a vaccine when one becomes available. It suggested four phases, which were based on the risk of acquiring infection, the risk of severe illness, the effect on societal functioning, and the risk of transmitting disease. ${ }^{11}$

In the first of these phases the vaccine would go to high risk healthcare workers, people whose conditions put them at high risk for serious illness, and older people living in nursing homes. In the second phase essential workers in critical industries and teachers and school staff would get the vaccine. The first two phases would include about half of the US population of 330 million.

In the third phase the vaccine would go to young adults and essential workers at increased risk who were not included in the earlier groups. The fourth phase would include everyone else.

\footnotetext{
Rauhala E, Abutaleb Y. US says it won't join WHO-linked effort to develop, distribute coronavirus vaccine. Washington Post20201 Sep. https://www.washing tonpost.com/world/coronavirus-vaccine-trump/2020/09/01/b44b42be-e965-11ea-bf44-0d31c85838a5_story.html.

Tanne JH. Experts protest Trump's withdrawal from WHO. BMJ2020;370:m2802. doi: 10.1136/bmj.m2802 pmid: 32651174

Torjesen I. Covid-19: Pre-purchasing vaccine-sensible or selfish?BM/2020;370:m3226. doi: 10.1136/bmj.m3226 pmid: 32816716

Stacey K. FDA head says he is willing to fast-track Covid-19 vaccine. Financial Times 2020 Aug 30. https://www.ft.com/content/f8ecf7b5-f8d2-4726-ba3f233b8497b91a.

Stacey K. Early vaccine approval is biggest test yet for FDA chief. Financial Times 2020 Aug 31. https://www.ft.com/content/21379dbd-8f46-4b29-b277560e98b807dc.

Levine D, Taylor M. Exclusive: Top FDA official says would resign if agency rubber-stamps an unproven COVID-19 vaccine. Reuters 2020 Aug 21. https://reut.rs/2QMyVBg.
} 
7 Christensen J. Past vaccine disasters show why rushing a coronavirus vaccine would be "colossally stupid." CNN Health 2020 Sep 1. https://www.cnn.com/2020/09/01/health/eua-coronavirus-vaccinehistory/index.html.

8 Charter D. Coronavirus vaccine: 1976 offers lesson in the dangers of haste. Times (London) 2020 Aug 25. https://www.thetimes.co.uk/article/coronavirus-vaccine-1976-offers-lesson-in-the-dangers-ofhaste-tvmdcdt50.

9 Department of Health and Human Services, Public Health Service, Food and Drug Administration, Center for Drug Evaluation and Research, Office of Surveillance and Epidemiology. Pharmacovigilance memorandum. 19 May 2020. https://www.accessdata.fda.gov/drugsatfda_docs/nda/2020/OSE\%20Review_Hydroxychloroquine-Cholorquine\%20-\%2019May2020_Redacted.pdf.

10 National Institutes of Health. The COVID-19 Treatment Guidelines Panel's statement on the emergency use authorization of convalescent plasma for the treatment of covid-19.1 Sep 2020. https://www.covid19treatmentguidelines.nih.gov/statement-on-convalescent-plasma-eua/.

11 National Academies of Sciences, Engineering, and Medicine. Discussion draft of the preliminary framework for equitable allocation of covid-19 vaccine. National Academies Press. 2020. doi: https://doi.org/10.17226/25914.

This article is made freely available for use in accordance with BMJ's website terms and conditions for the duration of the covid-19 pandemic or until otherwise determined by BMJ. You may use, download and print the article for any lawful, non-commercial purpose (including text and data mining) provided that all copyright notices and trade marks are retained. 